\title{
In vitro surface sterilization of the shoot tips of Bougainvillea spectabilis Willd
}

\author{
Izhar Ahmad ${ }^{1}$, Roshan Zamir ${ }^{2}$, Syed Tariq Shah ${ }^{2}$ and Sher Wali ${ }^{1 *}$ \\ 1. Department of Botany, Islamia College, Peshawar-Pakistan \\ 2. Nuclear Institute for Food and Agriculture (NIFA), Peshawar-Pakistan \\ *Corresponding author's email: sherwali@ icp.edu.pk \\ Citation \\ Izhar Ahmad, Roshan Zamir, Syed Tariq Shah and Sher Wali. In vitro surface sterilization of the shoot tips of \\ Bougainvillea spectabilis Willd. Pure and Applied Biology. Vol. 5, Issue 4, pp1171-1175. \\ http://dx.doi.org/10.19045/bspab.2016.50140
}

Received: 06/09/2016

Revised: 10/10/2016

Accepted: 14/10/2016

Online First: 28/10/2016

\section{Abstract}

In vitro studies were carried out to investigate the effects of different sterilants for the surface sterilization of the shoot tips of Bougainvillea spectabilis Willd. Three sterilints i.e. $\mathrm{HgCl}_{2}$, $\mathrm{NaOCl}, \mathrm{CaOCl}_{2}$ were selected to test their surface sterilization ability of the of Bougainvillea spectabilis Willd. The sterilants were for observing their surface sterilization potential in different concentrations and duration. Silver Chloride, $\mathrm{HgCl}_{2}(0.05 \%)$ for 3 minutes was found as the most effective sterilant with maximum survival percentage of $91.6 \%$ followed by $\mathrm{HgCl} 2$ $(0.05 \%)$ for 5 minutes with $75 \%$ survival. The minimum survival $(8.33 \%)$ was observed with $4 \%$ Calcium hypochlorite for 5 minutes.

Keywords: Sterilization; Shoot tips; Bougainvillea spectabilis; Sterilants; Survival percentage

\section{Introduction}

Bougainvillea (Bougainvillea spectabilis

Willd.) belongs to the Dicot family, Nyctaginaceae. The plant is a shrub, tree or vine, which can reach over 30 feet high. Its leaves are large, simple and mostly ovate [1, 2]. They may show rippling along the edges and hair can be seen underneath. Bracts are usually in shades of red, shades of dark pink or shades of purple. Thorns are large and may be curved. Flowers are cream coloured. Its habitat is dense and the bracts appear up and down the branches. During the dry season or in a cool spell, flowering is triggered. The root system is very fragile and doesn't form a good root ball [3].

Bougainvillea has many adaptations to its climate and environment. It lines in a climate from subtropical to dense forests where it can cling and grab onto others plants to reach the sunlight. It can tolerate semi-shaded areas and can also tolerate full sun. It thrives in full sun. At least $5 \mathrm{~h}$ a day of full sunlight is the minimum light required for a good bloom.

More hours of direct sun is better, the plant does not like to live with a lot of water. The plant has earned a reputation as to be the pride of gardens among the naturalists and ornamentalists due to its wide range of habitats, prolonged flowering seasons and variety of flower colours. It also has a wide range of uses in landscaping. The traditional multiplication of Bougainvillea is very difficult because of climatic conditions it does not produce seeds while from cutting the percentage of success is very low. The plants which are produced by air layering are in small quantity, need more skill and labour. So there is a need to adopt a 
technique known as tissue culture which consist in regeneration of cultivated plant species [4].

The micro-propagation of plants has allowed for strong and continued growth within the micro propagation industry. Tissue culture techniques have been successfully employed to produce large number of plant which are difficult to propagate as reported by [5]. Micro-propagation is rapid, efficient and plants can be produced year round for the market using this technique. The vegetative axillary buds of Bougainvillea have shown a promising subsequent plant regeneration [4, 15]. In vitro propagation needs effective sterilization of the explants. The explant taken from field grown plant are very difficult in tissue culture because of infestation with microorganisms [5]. Various concentrations and combinations of sterilants has been reported and used in preliminary trials in vitro on tissue of juvenile and adult trees explant of guava to see the effect of free infestation explant and also on its growth. Micro-propagation of Bougainvillea by shoot tip culture has been successful $[5,6,11]$. Taking into account, the economical and ornamental value of Bougainvillea, the aim of this study was to improve the micro-propagation through shoot tip culture.

Materials and methods

Bougainvillea spectabilis Willd. was selected for the present studies. Plant materials were collected from vigorously growing plants. $1 \mathrm{~cm}$ long shoot tips were treated with 3 drops of Zip as a detergent and then washed by running tap water for $1 / 2$ an hour to remove dust particles. The explants were surface sterilized with $70 \%$ ethanol for 30 seconds [9] followed by various sterilants in different concentrations and exposure time. $0.05 \%$ and $0.25 \%$ Mercuric Chloride for 1,3 and 5 minutes, $2 \%$ and $4 \%$ Sodium Hypochlorite $(\mathrm{NaOCl})$ and Calcium Hypochlorite $\left(\mathrm{CaOCl}_{2}\right)$ for 1,3 and 5 minutes were used according to the procedure of [11]. Then the shoot tips were rinsed three times with sterile distilled water in laminar flow bench to remove sterilants. All sterilization manipulations were carried out in laminar airflow hood.

Experiment was arranged in a randomized complete block design with three replications per treatment, each with 20 explants. The data were recorded after 5-7 weeks and statistically analyzed by using Duncan's Multiple Range Test [11], to check the level of significance between the treatments. These sterile were then grown MS nutrient media [8] under different hormones as mentioned [1].

\section{Results and discussion}

Application of different sterilants for surface sterilization on the shoot tips showed that the shoot tips treated with $0.05 \% \mathrm{HgCl}_{2}$ for 3 minutes (Figure 1C) showed maximum survival $(91.6 \%)$ while $0.05 \%$ and $0.25 \%$ $\mathrm{HgCl}_{2}$ for 5 and 3 minutes respectively gave (75\%) survival. $2 \% \mathrm{NaOCl}$ for 5 minutes and 1 minute gave $68.75 \%$ and $64.58 \%$ survival of shoot tips respectively (Figure 1B). $2 \% \mathrm{CaOCl}_{2}$ for 1 minute (Figure 1C) gave $30 \%$ survival of the shoot tips. Minimum survival of $8.33 \%$ was observed when the shoot tips were treated with $4 \%$ $\mathrm{CaOCl}_{2}$ for 5 minutes (Figure $1 \mathrm{C}$ ). Among the three sterilants used, $\mathrm{CaOCl}_{2}$ was found the worst for the sterilization of bougainvillea shoot tips. The explants treated with this sterilant did not show any growth after sterilization.

Surface sterilization of explants is an important preliminary step of in-vitro techniques. The explant is usually contaminated with dust and various microbial colonies and their removal from the explant is a pre-requisite for the in-vitro culturing [11]. We used three different types of sterilants for the sterilization of shoot tips and found that $\mathrm{HgCl}_{2}$ as the best sterilant giving higher percentage of the explant 
survival (Table 1 and Figure 1). The results are in line with those of $[5,10]$ who carried out surface sterilization with $0.05 \%$ solution of $\mathrm{HgCl}_{2}$ for 5 minutes followed by 3 washing with sterilized distilled water. $0.1 \%$ $\mathrm{HgCl} 2$ for five minutes in combination with $0.1 \%$ Sodium lauryl sulphate is the best sterilant for the surface sterilization of nodal explants of 22 cultivars [3]. $\mathrm{HGCl}_{2}$ is an effective sterilant for potato [2]. It is suggested that $\mathrm{HgCl}_{2}$ is very strong and highly toxic for the microbial colonies even in very low concentrations and shorter durations. $\mathrm{HgCl}_{2}$ may not only be harmful to the microbes but also may be the tissues of explant as we observe the blackening of the shoot tips.

$2 \% \mathrm{NaOCl}$ for 5 minutes was found as the second best sterilant with $68.75 \%$ survival (Figure 1B). $\mathrm{NaOCl}$ is reported as one of the effective surface sterilant for the cotyledon explant of Arachis hypogea [6]. This sterilant was not only effective for sterilization but also showed better growth of the explants after sterilization in contrast to $\mathrm{HgCl}_{2} .2 \% \mathrm{NaOCl}$ is used for sterilization of shoot tips of Bougainvillea but the time of exposure is not known [4].

Table 1. Effects of various sterilants on survival percentage of guava shoot tip

\begin{tabular}{|c|c|c|c|c|}
\hline S. No. & Sterilants/strength/time & $\begin{array}{l}\text { No. of shoot tips } \\
\text { contaminated }\end{array}$ & $\begin{array}{c}\text { No. of shoot tip } \\
\text { survived }\end{array}$ & Survival \% \\
\hline 1 & $\mathrm{HgCl}_{2} 0.05 \%$ for 1 minute & 15 & $33 \mathrm{BC}$ & 68.75 \\
\hline 2 & $\mathrm{HgCl}_{2} 0.05 \%$ for 3 minutes & 4 & $44 \mathrm{~A}$ & 91.6 \\
\hline 3 & $\mathrm{HgCl}_{2} 0.05 \%$ for 5 minutes & 22 & $36 \mathrm{~B}$ & 75.0 \\
\hline 4 & $\mathrm{HgCl}_{2} 0.25 \%$ for 1 minute & 29 & $28 \mathrm{CD}$ & 58.33 \\
\hline 5 & $\mathrm{HgCl}_{2} 0.25 \%$ for 3 minutes & 12 & $36 \mathrm{~B}$ & 75.0 \\
\hline 6 & $\mathrm{HgCl}_{2} 0.25 \%$ for 5 minutes & 21 & $27 \mathrm{CD}$ & 56.25 \\
\hline 7 & $\mathrm{NaOCl} 2 \%$ for 1 minute & 17 & $31 \mathrm{BCD}$ & 64.58 \\
\hline 8 & $\mathrm{NaOCl} 2 \%$ for 3 minutes & 23 & $25 \mathrm{D}$ & 52.08 \\
\hline 9 & $\mathrm{NaOCl} 2 \%$ for 5 minutes & 15 & $33 \mathrm{BC}$ & 68.75 \\
\hline 10 & $\mathrm{NaOCl} 4 \%$ for 1 minute & 21 & $27 \mathrm{CD}$ & 56.25 \\
\hline 11 & $\mathrm{NaOCl} 4 \%$ for 3 minutes & 18 & $30 \mathrm{BCD}$ & 62.5 \\
\hline 12 & $\mathrm{NaOCl} 4 \%$ for 5 minutes & 24 & $24 \mathrm{D}$ & 50.0 \\
\hline 13 & $\mathrm{CaOCl}_{2} 2 \%$ for 1 minute & 35 & $31 \mathrm{BCD}$ & 30 \\
\hline 14 & $\mathrm{CaOCl}_{2} 2 \%$ for 3 minutes & 39 & $9 \mathrm{EF}$ & 18.75 \\
\hline 15 & $\mathrm{CaOCl}_{2} 2 \%$ for 5 minutes & 39 & $9 \mathrm{EF}$ & 18.75 \\
\hline 16 & $\mathrm{CaOCl}_{2} 4 \%$ for 1 minute & 39 & $9 \mathrm{EF}$ & 18.75 \\
\hline 17 & $\mathrm{CaOCl}_{2} 4 \%$ for 3 minutes & 42 & $6 \mathrm{EF}$ & 12.5 \\
\hline 18 & $\mathrm{CaOCl}_{2} 4 \%$ for 5 minutes & 44 & $4 \mathrm{EF}$ & 8.33 \\
\hline
\end{tabular}

Means of same category followed by different letters are statistically different from each other at 5\%level of significance using LSD test 
Figure 1. Percentage survival rates of the shoot tips under different conditions

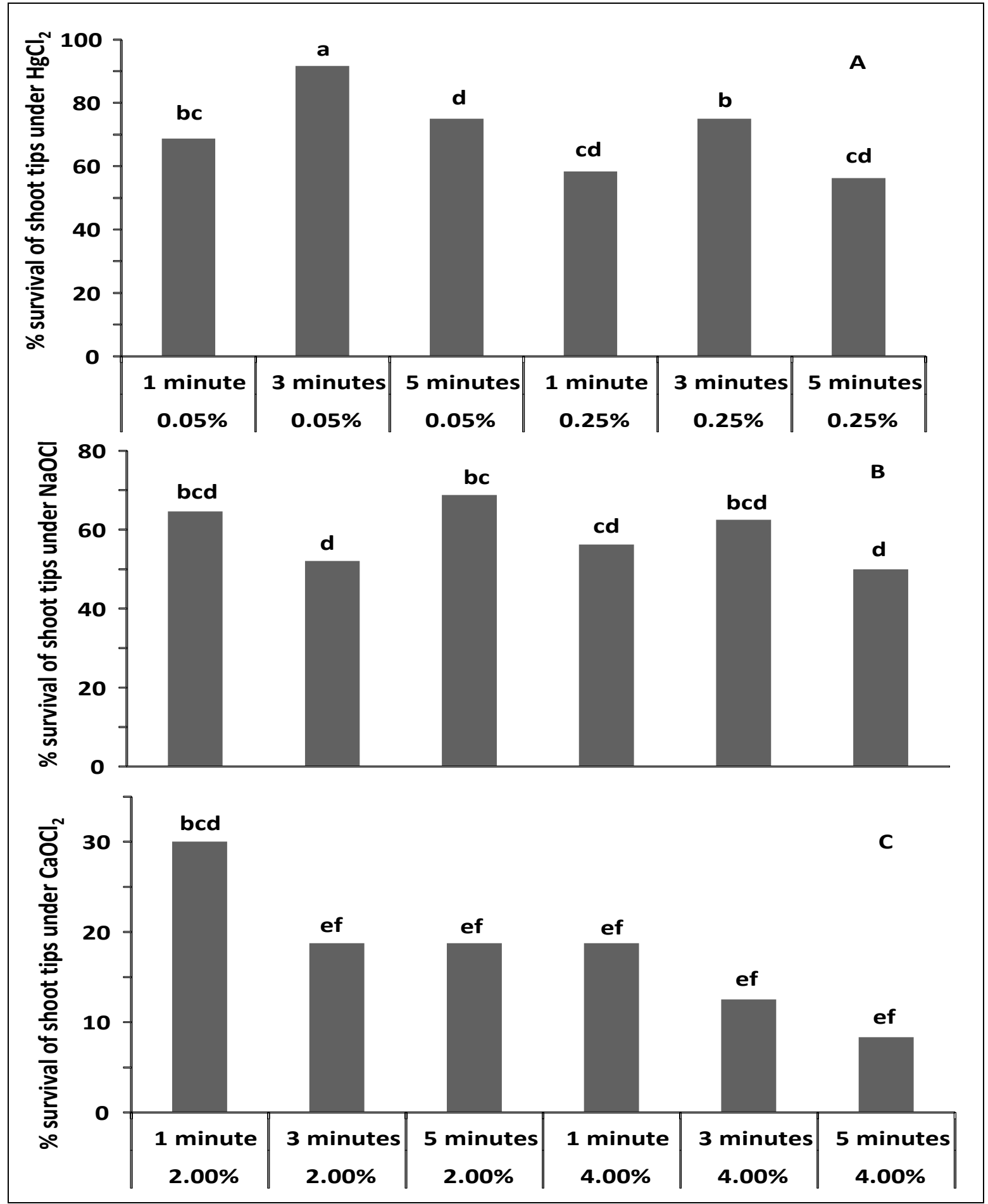

\section{Conclusion}

It is concluded that $\mathrm{HgCl}_{2}$ is effective sterilant for the shoot tips explant of Bougainvillea; however, the growth after the sterilization is negatively affected. On the other hand, $\mathrm{NaOCl}$ is less effective than $\mathrm{HgCl}_{2}$ but nevertheless maximum growth of shoot tips was observed after sterilization. $\mathrm{CaOCl}_{2}$ was found not only least effective 
sterilant but also having lethal effects on the shoot tips.

\section{Authors' contributions}

Conceived and designed the experiments: I Ahmad, Performed the experiments: R Zamir, ST Shah \& S Wali, Analyzed the data: I Ahmad \& S Wali, Contributed reagents/ materials/ analysis tools: I Ahmad, Wrote the paper: I Ahmad \& S Wali.

\section{References}

1. Ahmad L, Lutfullah G, Zamir R \& Shah ST (2007). In vitro response of various growth regulators on the regeneration of Bougainvillea spectabilis Willd. Suranaree Journal of Science and Technology 14(2): 157-162

2. Badoni A \& Chauhan JS (2010). In vitro sterilization protocol for micropropagation of Solanum tuberosum cv. Kufri Himilini. Academia Arena 2(4): 24-27

3. Gopal J, Minocha JL \& Dhaliwal HS (1998). Microtuberization in potato (Solanum tuberosum L.). Plant and Cell Reproduction 17: 794-798

4. Javed MA, Hassan S \& Nazir S (1996). In vitro propagation of Bougainvillea spectabilis through shoot apex culture. Pakistan Journal of Botany 28(2): 207211

5. Khattak MS, Malik MN \& Khan MA (1990). Effects of surface sterilization agents on in vitro culture of guava (Psidium guajava L.) Cv. Sufeda tissue.
Sarhad Journal of Agriculture 6(2): 151-154.

6. Maina SM, Emongor Q, Sharma KK, Gichuki ST, Gathaara M \& De Villiers SM (2010). Surface sterilant effect on the regeneration of efficiency from cotyledons explants of groundnut (Arachis hypogea L) varieties adapted to eastern and southern Africa. African Journal of Biotechnology 9(20): 28662871

7. Miller SA \& Lipschutz L (1984). Potato in: Ammirato P.V., Evans, D., Sharp W. R. and Yamada Yasuguki (eds.), Handbook of plant tissue culture, New York. McMillan publishing company 3: 291-293

8. Murashige $\mathrm{T}$ \& Skoog F (1962). A revised medium for rapid growth and bioassay with tobacco tissue culture. Physiologia Plantarum 15: 473-497

9. Naik PS \& Chandra R (1993). Use of tissue culture techniques in crop improvement with special reference to potato. CPRI, Shimla.

10. Steel RGD \& Torie JH (1980). Principles and procedures of statistics. McGraw Hill. NY.

11. Zamir R, Khattak GS, Mohammad T, Shah SA, Khan AJ \& Ali N (2004). In vitro mutagenesis in guava (Psidium guajava L.). Pakistan Journal of Botany 35(5): 825-828. 